\title{
ANALISIS FAKTOR PENGGUNAAN KONTRASEPSI METODE OPERATIF WANITA (MOW) PADA WANITA USIA SUBUR
}

\author{
ANALYSIS OF THE USING TUBAL LIGATION CONTRACEPTION (MOW) \\ IN WOMEN OF CHILDBEARING AGE
}

\author{
Naila Amalia Ischa \\ Departemen Biostatistika dan Kependudukan \\ Fakultas Kesehatan Masyarakat Universitas Airlangga \\ J1. Mulyorejo Kampus C Unair Surabaya 60115 \\ Alamat Email : ischanaila@yahoo.com
}

\begin{abstract}
MOW contraception is a long-term contraception method that has relatively small value of failure and free of side effects. People who interested in MOW contraception is still low, compared with other long-term contraception. This research was conducted to determine what factors influence MOW contraception use in women of childbearing age. MOW contraception factors is husband and family support, psychological costs, cost of contraception services, and birth control motivation.

This research was an analytic research with observational approach. The type of this research was the case control. The sampling using random sampling technique with a sample of 80 respondents, consist of 40 case samples and 40 control samples. The result test that being used in the Multivariate Logistic Regression Test with husband support variable and psychological costs with significant effect.

Husband support variable has a value of $p=0.027$ with $O R=4,143$ and psychological costs variable has a value of $p=0,039$ with $O R=2,698$. Women of childbearing age who had a husband's support will likely use contraception MOW 4,143 and women of childbearing age who do not have the psychological costs likely to use contraseption MOW 2,698.
\end{abstract}

Keywords: contraception, tubal ligation, women of childbearing age, determine 


\begin{abstract}
ABSTRAK
Kontrasepsi MOW merupakan metode kontrasepsi jangka panjang yang mempunyai nilai kegagalan relatif kecil dan bebas efek samping. Namun peminat kontrasepsi MOW masih rendah, dibandingkan dengan kontrasepsi jangka panjang lainnya. Penelitian ini dilakukan untuk mengetahui faktor apa yang mempengaruhi penggunaan kontrasepsi MOW pada wanita usia subur. Faktor wanita usia subur untuk menggunakan kontrasepsi MOW dipengaruhi oleh dukungan suami, dukungan keluarga, biaya psikologis, biaya pelayanan kontrasepsi dan motivasi pengaturan kelahiran.

Penelitian ini merupakan penelitian analitik dengan pendekatan observasional. Jenis penelitian adalah case control. Sampling menggunakan teknik random sampling dengan sampel sebanyak 80 responden (40 sampel kasus dan 40 sample kontrol). Uji yang digunakan adalah Uji Regresi Logistik Multivariat dengan hasil variabel dukungan suami dan biaya psikologis yang berpengaruh secara signifikan.

Variabel dukungan suami memiliki nilai $p=0,027$ dengan $O R=4,143$. Sedangkan variabel biaya psikologis memiliki nilai $\mathrm{p}=0,039$ dengan $\mathrm{OR}=2,698$. Wanita usia subur yang memiliki dukungan suami akan berpeluang 4,143 menggunakan kontrasepsi MOW dan yang tidak memiliki biaya psikologis berpeluang 2,698 menggunakan kontrasepsi MOW.
\end{abstract}

\title{
Kata kunci: kontrasepsi, MOW, wanita usia subur, determinan
}

\section{PENDAHULUAN}

Permasalahan utama kuantitas penduduk adalah pertumbuhan yang masih cukup tinggi. Dalam jangka panjang, kondisi kependudukan yang diinginkan adalah tercapainya penduduk stabil dalam jumlah yang tidak terlalu besar. Negara Indonesia saat ini menempati urutan keempat dengan jumlah penduduk tertinggi di dunia (BPS, 2015).

Hasil sensus penduduk tahun 2015 menunjukkan jumlah penduduk Indonesia sebanyak 255,5 juta jiwa dengan laju pertumbuhan penduduk per tahun sebesar 1,8\% (BPS, 2015). Provinsi Jawa Timur mengalami kondisi yang tidak jauh berbeda dengan Indonesia. Pada tahun 2010 jumlah penduduk Provinsi Jawa Timur sebesar 37.476.757 jiwa.

Pada masa reformasi program KB mengalami stagnasi, selama kurun waktu 10 tahun terakhir pemerintah belum mampu menurunkan total fertility rate (TFR) yang mencapai 2,6, angka ini masih jauh dari target yaitu sebesar 2,1 (SDKI, 2012). Menurut Undang-Undang RI Nomor 52 Tahun 2009, keluarga berencana adalah upaya mengatur kelahiran anak, jarak dan usia ideal melahirkan, mengatur kehamilan, melalui promosi, perlindungan dan bantuan sesuai dengan hak reproduksi untuk mewujudkan keluarga yang berkualitas.

Pelaksanaan program KB diarahkan untuk menurunkan tingkat kelahiran atas dasar kesadaran dan tanggung jawab seluruh masyarakat melalui pemilihan metode kontrasepsi secara sukarela dengan peningkatan penggunaan metode kontrasepsi jangka panjang (MKJP) seperti Intra Uterine Device (IUD), implan dan sterilisasi (Fienalia, 2012). Menurut BKKBN Jawa Timur (2015), peserta KB Baru di Provinsi Jawa Timur tahun 2015 yang menggunakan metode kontrasepsi jangka penden sebesar $83,22 \%$ dan metode kontrasepsi jangka panjang seperti IUD, implan, MOP dan MOW hanya sebesar $16,78 \%$.

Penggunaan kontrasepsi berkaitan dengan kesehatan reproduksi yang merupakan bagian dari kesehatan ibu. Ketidakberhasilan kontrasepsi yang digunakan oleh wanita usia subur yang ingin mengakhiri kelahiran dapat menyebabkan terjadinya kehamilan yang tidak diinginkan (Winner, et al, 2012). Dampak yang lebih serius yaitu jika kehamilan terjadi pada ibu usia diatas 35 tahun, anak lebih dari 3 orang dan jarak kehamilan terlalu dekat (Kemenkes, 2013).

Salah satu alat kontrasepsi yang bisa menekan laju pertumbuhan penduduk dan 
penting bagi kesehatan ibu adalah kontrasepsi MOW. Kontrasepsi mantap MOW merupakan salah satu metode kontrasepsi jangka panjang yang mempunyai nilai kegagalan yang relatif kecil, yaitu 1 kehamilan per 100 wanita selam tahun pertama setelah melakukan prosedur sterilisasi. Sterilisasi ini tidak memberikan efek samping jangka panjang dan lebih efektif untuk mencegah kehamilan (WHO, 2011).

Permasalahan mendasar hingga saat ini adalah peminat kontrasepsi MOW masih sangat rendah (Depkes, 2010). Jika dibandingkan dengan kontrasepsi jangka panjang lainnya seperti IUD dan implan, kontrasepsi MOW memang lebih bersifat permanen artinya untuk mengakhiri kesuburan.

Banyak faktor yang mempengaruhi keputusan wanita usia subur untuk menggunakan atau tidak menggunakan kontrasepsi MOW. Beberapa faktor yang berpengaruh terhadap penggunaan kontrasepsi MOW yaitu cost of regulation fertility meliputi dukungan suami, dukungan keluarga, biaya psikologis, biaya pelayanan kontrasepsi dan motivasi pengaturan kelahiran (Bulatao, 1983). Penelitian Stephenson (2006) menunjukkan bahwa banyak potensi penggunaan kontrasepsi MOW memilih tidak menggunakan kontrasepsi MOW karena kesalahan persepsi dan kekahawatiran akan risiko kesehatan.

Kabupaten Bojonegoro merupakan salah satu Kabupaten perbatasan di Provinsi Jawa Timur dengan pencapaian kontrasepsi yang baik, yaitu dengan menempati urutan lima besar pencapaian peserta KB Baru di Provinsi Jawa Timur (Dinkes Jatim, 2012). Namun prestasi ini tidak diimbangi dengan proporsi penggunaan kontrasepsi MKJP di Kabupaten Bojonegoro yang masih rendah, terutama peserta kontrasepsi MOW masih dibawah capaian Nasional dan Provinsi Jawa Timur. Pemerintah telah menerapkan berbagai strategi untuk meningkatkan penggunaan kontrasepsi MOW pada wanita usia subur. Salah satunya dengan memberikan pelayanan gratis pada akseptor kontrasepsi MOW, memberikan insentif kepada petugas kesehatan dan kader, memberikan kemudahan akses dan persyaratan prosedur pelaksanaan sterilisasi.

Proporsi peserta KB Baru MOW di Kabupaten Bojonegoro meskipun masih rendah, tetapi mengalami kenaikan setiap tahunnya. Peserta KB Baru MOW di Puskesmas Sumberrejo mengalami peningkatan setiap tahunnya dan melebihi capaian Kabupaten Bojonegoro (1,2\%) dan Provinsi Jawa Timur (1,38\%) (Profil Dinkes Kabupaten Bojonegoro, 2014).

Pemahaman mengenai mengapa wanita usia subur memilih serta tidak memilih menggunakan kontrasepsi MOW sangat penting untuk menentukan perencanaan dan pengembangan program KB di Jawa Timur terutama di Kabupaten Bojonegoro. Penelitian mengenai faktor yang berpengaruh terhadap penggunaan kontrasepsi MOW nantinya dapat dijadikan sebagai acuan dalam menentukan upaya peningkatan cakupan peserta KB metode kontrasepsi MOW.

Penelitian ini bertujuan untuk menganalisis faktor yang berpengaruh terhadap penggunaan kontrasepsi MOW pada wanita usia subur di wilayah kerja Puskesmas Sumberrejo Kabupaten Bojonegoro. Pertama, mengidentifikasi karakteristik berdasarkan variabel yang diteliti. Kedua, menganalisis faktor yang berpengaruh pada variabel penelitian.

\section{METODE PENELITIAN}

Jenis penelitian merupakan penelitian analitik dengan melakukan analisa terhadap data yang telah diperoleh. Pendekatan penelitian menggunakan pendekatan observasional. Desain penelitian yaitu case control dengan melakukan pengelompokkan kelompok kasus dan kontrol.

Responden penelitian terbagi menjadi dua kelompok sesuai dengan desain penelitian case control. Responden penelitian yaitu wanita usia subur akseptor kontrasepsi MOW, IUD, dan implan tahun 2013-2015 di wilayah kerja Puskesmas Sumberrejo Kabupaten Bojonegoro. 
Responden pada kelompok kasus adalah wanita usia subur akseptor kontrasepsi MOW. Responden pada kelompok kontrol adalah wanita usia subur akseptor kontrasepsi IUD dan Implan.

Wanita usia subur akseptor kontrasepsi MOW yang tercatat dalam buku register KB Puskesmas Sumberrejo adalah 61 orang. Wanita usia subur akseptor kontrasepsi IUD dan implan yang tercatat dalam buku register KB Puskesmas Sumberrejo adalah sebanyak 263 orang. Pemilihan responden menggunakan teknik simple random sampling.

Menurut perhitungan rumus Lemeshow (1997) sampel dalam penelitian didapatkan hasil yaitu 40 orang. Perbandingan antara sampel kasus dengan sampel kontrol adalah 1:1. Jumlah sampel yaitu 40 sampel kasus dan 40 sampel kontrol.

Waktu penelitian dimulai pada bulan Mei sampai Juli 2016. Variabel dalam penelitian adalah variabel terikat yaitu penggunaan kontrasepsi MOW. Variabel bebas yaitu dukungan suami, dukungan keluarga, biaya psikologis, biaya pelayanan kontrasepsi dan motivasi pengaturan kelahiran.

Data sekunder yaitu jumlah peserta KB diperoleh dari data BKKBN Kantor Perwakilan Provinsi Jawa Timur, BPPKB Kabupaten Bojonegoro dan data akseptor yang ada di wilayah kerja Puskesmas Sumberrejo. Data primer diperoleh dari kuisioner yang disebarkan kepada responden. Teknik pengolahan dan analisa data menggunakan komputer dengan program statistik dan uji Regresi Logistik.

\section{HASIL PENELITIAN DAN PEMBAHASAN}

Tabel 1. Sebaran Variabel Independen Terhadap Penggunaan Kontrasepsi MOW

\begin{tabular}{|c|c|c|c|c|}
\hline \multirow{2}{*}{ Variabel } & \multirow{2}{*}{ Kategori } & \multicolumn{2}{|c|}{ Penggunaan MOW } & \multirow{2}{*}{ Jumlah } \\
\hline & & MOW & Non MOW & \\
\hline \multirow[t]{3}{*}{ Dukungan suami } & Mendukung & $13(76,5 \%)$ & $4(23,5 \%)$ & 17 \\
\hline & Tidak mendukung & $27(42,9 \%)$ & $36(57,1 \%)$ & 63 \\
\hline & Jumlah & $40(50,0 \%)$ & $40(50,0 \%)$ & 80 \\
\hline \multirow[t]{3}{*}{ Dukungan keluarga } & Mendukung & $16(43,2 \%)$ & $21(57,8 \%)$ & 37 \\
\hline & $\begin{array}{c}\text { Tidak } \\
\text { mendukung }\end{array}$ & $24(55,8 \%)$ & $19(44,2 \%)$ & 43 \\
\hline & Jumlah & $40(50,0 \%)$ & $40(50,0 \%)$ & 80 \\
\hline \multirow[t]{3}{*}{ Biaya psikologis } & Ada beban & $13(36,1 \%)$ & $23(63,9 \%)$ & 36 \\
\hline & Tidak ada beban & $27(61,4 \%)$ & $17(38,6 \%)$ & 44 \\
\hline & Jumlah & $40(50,0 \%$ & $40(50,0 \%)$ & 80 \\
\hline \multirow[t]{3}{*}{ Biaya pelayanan kontrasepsi } & Ada biaya & $14(58,3 \%)$ & $10(41,7 \%)$ & 24 \\
\hline & Tidak ada biaya & $26(46,4 \%)$ & $30(53,6 \%)$ & 56 \\
\hline & Jumlah & $40(50,0 \%)$ & $40(50,0 \%)$ & 80 \\
\hline \multirow[t]{4}{*}{ Motivasi pengaturan kelahiran } & Tinggi & $16(51,6 \%)$ & $15(48,4 \%)$ & 31 \\
\hline & Sedang & $19(57,6 \%)$ & $14(42,4 \%)$ & 33 \\
\hline & Rendah & $5(31,3 \%)$ & $11(68,7 \%)$ & 16 \\
\hline & Jumlah & $40(50,0 \%)$ & $40(50,0 \%)$ & 80 \\
\hline
\end{tabular}

Karakteristik responden hasil penelitian dapat dilihat pada tabel 1 . Dukungan suami responden terbagi dalam dua kategori yaitu mendukung dan tidak mendukung. Diperoleh hasil bahwa responden yang menggunakan kontrasepsi MOW 76,5\% mendapatkan dukungan dari suaminya, sebesar $42,9 \%$ yang menggunakan kontrasepsi MOW tidak mendapatkan dukungan suaminya.
Responden yang tidak menggunakan kontrasepsi MOW, sebesar 23,5\% mendapatkan dukungan suami, sedangkan $57,1 \%$ responden tidak mendapatkan dukungan suaminya.

Dukungan keluarga terbagi menjadi dua kategori yaitu mendukung dan tidak mendukung. Responden yang menggunakan kontrasepsi MOW sebesar $55,8 \%$ tidak mendapatkan dukungan 
keluarga, responden yang mendapatkan dukungan keluarga dan menggunakan kontrasepsi MOW hanya sebesar 43,2\%. Sedangkan responden yang tidak menggunakan kontrasepsi MOW dan mendapatkan dukungan keluarga sebesar $57,8 \%$, responden yang tidak menggunakan kontrasepsi MOW dan tidak mendapatkan dukungan keluarga sebesar 44,2\%.

Biaya psikologis terbagi menjadi dua kategori yaitu ada beban dan tidak ada beban. Responden yang menggunakan kontrasepsi MOW sebesar 61,4\%

menyatakan bahwa tidak ada beban psikologis dan sebesar $36,1 \%$ menyatakan ada beban dalam penggunaan kontrasepsi MOW. Sedangkan responden yang tidak menggunakan kontrasepsi MOW, sebesar $63,9 \%$ menyatakan ada beban pskologis dan sebesar 38,6\% tidak ada beban psikologis dalam penggunaan kontrasepsi.

Biaya pelayanan dalam penggunaan kontrasepsi terbagi menjadi dua kategori yaitu ada biaya dan tidak ada biaya. Responden sebesar 58,3\% menyatakan ada biaya pelayanan dalam penggunaan kontrasepsi MOW, sebesar 46,4\% yang menggunakan kontrasepsi MOW tidak ada biaya pelayanan. Sedangkan responden yang tidak menggunakan kontrasepsi MOW sebesar 53,6\% tidak ada biaya pelayanan dan hanya sebesar $41,7 \%$ yang menyatakan ada biaya pelayanan dalam penggunaan kontrasepsi.

Motivasi pengaturan kelahiran terbagi menjadi tiga kategori yaitu tinggi, sedang, dan rendah. Responden yang menggunakan kontrasepsi MOW sebesar 57,6\% memiliki motivasi pengaturan kelahiran tergolong sedang, sebesar $51,6 \%$ tergolong sedang dan hanya sebesar $31,3 \%$ yang memiliki motivasi rendah. Sedangkan responden yang tidak menggunakan kontrasepsi MOW sebesar 68,7\% memiliki motivasi rendah dalam pengaturan kelahiran, 48,4\% memiliki motivasi tergolong tinggi dan 42,4\% memiliki motivasi sedang dalam pengaturan kelahiran.

Uji regresi logistik dilakukan untuk mengetahui faktor yang mempengaruhi penggunaan kontrasepsi MOW pada wanita usia subur. Reference variabel pada variabel dependen adalah wanita usia subur yang menggunakan kontrasepsi MOW. Sedangkan pada variabel independen yang menjadi reference variabel pada variabel dukungan suami adalah kategori mendukung dan biaya psikologis adalah kategori tidak ada beban.

Tabel 2. Hasil Uji Regresi Logistik

\begin{tabular}{|c|c|c|c|}
\hline Variabel & Nilai $p$ & Keterangan & OR \\
\hline $\begin{array}{l}\text { Dukungan } \\
\text { suami }\end{array}$ & 0,019 & Berpengaruh & 4,143 \\
\hline $\begin{array}{l}\text { Dukungan } \\
\text { keluarga }\end{array}$ & 0,263 & $\begin{array}{c}\text { Tidak } \\
\text { berpengaruh }\end{array}$ & - \\
\hline Biaya psikologis & 0,026 & Berpengaruh & 2,698 \\
\hline $\begin{array}{l}\text { Biaya pelayanan } \\
\text { kontrasepsi }\end{array}$ & 0,331 & $\begin{array}{c}\text { Tidak } \\
\text { berpengaruh }\end{array}$ & - \\
\hline $\begin{array}{l}\text { Motivasi } \\
\text { pengaturan } \\
\text { kelahiran }\end{array}$ & 0,240 & $\begin{array}{c}\text { Tidak } \\
\text { berpengaruh }\end{array}$ & - \\
\hline Konstanta & 0,029 & - & - \\
\hline
\end{tabular}

Tabel 2 menunjukkan bahwa variabel dukungan suami dan biaya psikologis memiliki pengaruh yang signifikan terhadap penggunaan kontrasepsi MOW. Variabel dukungan suami dengan nilai signifikan sebesar 0,019 dan OR 4,413. Kesimpulannya bahwa wanita usia subur yang mendapatkan dukungan suami memiliki peluang 4,143 lebih besar untuk menggunakan kontrasepsi MOW dibandingkan dengan yang tidak mendapatkan dukungan suami. Biaya psikologis dengan nilai signifikan sebesar 0,039 dan OR 2,698. Wanita usia subur yang tidak memiliki beban psikologis berpeluang 2,698 untuk menggunakan kontrasepsi MOW dari pada wanita usia subur yang memiliki beban psikologis.

\section{PEMBAHASAN}

\section{Faktor yang Mempengaruhi Penggunaan Kontrasepsi MOW Karakteristik Dukungan suami}

Hasil penelitian menunjukkan bahwa faktor dukungan suami merupakan salah satu faktor yang berpengaruh signifikan terhadap penggunaan kontrasepsi MOW. Wanita usia subur yang mendapatkan dukungan suami cenderung memilih menggunakan kontrasepsi MOW. Sebaliknya, wanita usia subur yang tidak 
mendapatkan dukungan suami cenderung tidak menggunakan kontrasepsi MOW.

Hasil penelitian sejalan dengan hasil OR, yaitu wanita usia subur yang mendapatkan dukungan suami memiliki peluang 4,349 lebih besar untuk menggunakan kontrasepsi MOW dari pada yang tidak mendapatkan dukungan suami. Hal ini sesuai dengan penelitian yang telah dilakukan oleh Siquera (2007), yang menyatakan bahwa hanya 6\% keputusan menggunakan kontrasepsi sterilisasi atas saran dari suami.

Suami merupakan partner ibu dalam menjalani kehidupan. Peran suami sangat berpengaruh dalam psikologis ibu serta pengambilan keputusan ibu khususnya dalam pengambilan keputusan menggunakan tidaknya kontrasepsi MOW. Kesadaran suami dalam keikutsertaan berpartisipasi dalam menentukan alat kontrasepsi yang sesuai menunjukkan kepedulian bahwa masalah kesehatan reproduksi bukan hanya masalah wanita.

Partisipasi pria dalam upaya mendukung program KB bukan hanya dengan mengantar istrinya ke pelayanan kesehatan atau sekedar memberikan materi finansial, tetapi dengan ikut mendampingi pasangannya baik pada saat pemasangan maupun saat penyuluhan atau konseling. Hartanto (2004) dalam Fienalia (2012) mengatakan bahwa istri tidak dapat memilih metode kontrasepsi tanpa adanya kerjasama suami dan saling percaya.

Saling memberikan dukungan dalam memilih dan memutuskan untuk menggunakan jenis kontrasepsi sangat berpengaruh terhadap tingkat keberhasilan dalam program keluarga berencana (Ernest et al., 2007). Perempuan Akseptor KB merasa lebih nyaman ketika keputusan KB diputuskan secara mufakat antara pasangan. Alasan banyaknya wanita usia subur yang tidak menggunakan kontrasepsi MOW dikarenakan tidak mendapat dukungan dan tidak disetujui oleh suami (Sahin, 2003).

\section{Karakteristik Biaya Psikologis}

Berdasarkan hasil analisis regresi, diketahui bahwa faktor biaya psikologis merupakan salah satu faktor yang berpengaruh signifikan terhadap penggunaan kontrasepsi MOW. Wanita usia subur yang tidak memiliki beban psikologis cenderung memilih menggunakan kontrasepsi MOW. Sebaliknya, wanita usia subur yang memiliki beban psikologis cenderung tidak menggunakan kontrasepsi MOW.

Hasil penelitian tersebut sejalan dengan OR, yaitu wanita usia subur yang tidak memiliki beban psikologis memiliki peluang 2,698 lebih besar untuk menggunakan kontrasepsi MOW dari pada wanita yang memiliki beban psikologis. Hal ini tentunya tidak terlepas dari keuntungan penggunaan kontrasepsi MOW yang relatif bebas efek samping, sehingga wanita usia subur merasa tidak khawatir akan adanya kegagalan kontrasepsi.

Wanita usia subur merasa tidak terganggu dengan pendapat masyarakat sekitar mengenai hukum dari penggunaan kontrasepsi. Kontrasepsi MOW atau sterilisasi dibolehkan dengan alasan medis dan darurat, yaitu apabila tidak dilaksanakan dapat membahayakan jiwa ibu atau anak (BKKBN, 2011).

Andrews (2009) menyatakan bahwa banyak wanita merasakan kebebasan setelah melakukan sterilisasi. Wanita usia subur tidak lagi mengalami kecemasan karena bergantung pada satu metode kontrasepsi yang membuat mereka tidak nyaman dan kekhawatiran terhadap terjadinya kehamilan menjadi berkurang. Metode kontrasepsi MOW yang dapat menghilangkan kecemasan ini memfasilitasi wanita dalam mengeksplorasi seksualitas mereka dan menikmati aktivitas seks dengan cara yang sebelumnya tidak dapat mereka rasakan.

\section{Faktor yang Tidak Mempengaruhi Penggunaan Kontrasepsi MOW}

\section{Karakteristik Motivasi Pengaturan Kelahiran}

Motivasi pengaturan kelahiran tidak berpengaruh signifikan terhadap penggunaan kontrasepsi MOW. Motivasi pengaturan kelahiran ditentukan oleh dua faktor, yaitu jumlah anak yang diinginkan (demand for children) dan jumlah anak hidup (supply for children). Apabila jumlah 
anak yang diinginkan sudah terpenuhi, maka wanita usia subur akan cenderung termotivasi dalam menggunakan alat kontrasepsi. Sebaliknya jika wanita usia subur dengan supply melebihi demand, seharusnya dimotivasi untuk mengatur atau membatasi jumlah kelahiran anaknya (Bulatao, 1983).

Keinginan akan jumlah anak tertentu (demand for children) pada pasangan suami istri tidak selalu terpenuhi. Hal ini bergantung pada kemampuan ibu untuk hamil dan melahirkan anak. Apabila jumlah anak yang diinginkan belum terpenuhi maka motivasi pasangan suami istri untuk menggunakan alat kontrasepsi MOW akan rendah. Sebaliknya, apabila jumlah anak yang diinginkan sudah terpenuhi maka kemampuan ibu untuk menggunakan kontrasepsi MOW dapat meningkat.

Banyaknya anak yang dimiliki oleh pasangan suami istri akan memberikan dorongan motivasi dalam diri istri untuk ikut menjadi akseptor KB. Keluarga yang telah mempunyai anak banyak (lebih dari 2 orang) diharapkan untuk menggunakan kontrasepsi yang efektif dibandingkan dengan keluarga yang masih mempunyai anak sedikit (paling banyak 2 orang).

Hasil penelitian Stephenson (2006) menyatakan bahwa terdapat pengaruh bermakna antara jumlah anak masih hidup dengan pemakaian kontrasepsi. Wanita yang mempunyai anak $\geq 3$ orang akan cenderung menggunakan kontrasepsi sterilisasi.

Motivasi pengaturan kelahiran ini tidak hanya menjadi urusan istri saja, melainkan juga melibatkan orang lain di sekitar istri. Motivasi adalah semua hal verbal, fisik, atau psikologis yang membuat seseorang melakukan sesuatu sebagai respon (Danim, 2004). Apabila pihak suami tidak memberikan pendapat atau ikut terlibat dalam keputusan pengaturan kelahiran, tentunya istri tidak akan termotivasi untuk membatasi kelahiran.

\section{Karakteristik Dukungan Keluarga}

Dukungan keluarga tidak berpengaruh signifikan dalam penggunaan kontrasepsi MOW. Kemungkinan karena wanita usia subur telah mendapatkan dukungan dari suaminya sebagai orang terdekat yang paling mempengaruhi keputusan istri dalam mengambil keputusan menggunakan kontrasepsi MOW. Selain itu, wanita usia subur yang memilih menggunakan kontrasepsi MOW cenderung sudah memiliki niat yang mantap dalam mengambil keputusan yang berhubungan dengan kesehatan reproduksinya. Menurut Ajzen (1986) dalam The Theory of Planned Behavior (Teori Perilaku Berencana) menyeburkan bahwa jika seseorang akan berperilaku kesehatan harus melewati faktor niat.

Menurut Friedman (1998) dukungan keluarga merupakan salah satu faktor yang sangat berpengaruh terhadap perilaku positif. Peran dukungan keluarga sendiri terbagi menjadi peran formal, misalnya peran informasi seperti bantuan langsung dari keluarga. Sebagian wanita usia subur mengaku bahwa dalam lingkungan keluarganya tidak ada yang memberikan informasi maupun saran serta memberikan pengalaman dan pembelajaran mengenai kontrasepsi MOW.

Keluarga merupakan bagian dari individu dalam proses pengambilan keputusan. Rodgers (2010) menyatakan bahwa keluarga dapat ikut mempengaruhi perencanaan dan kesejahteraan anak, "It promotes family ownership of the meeting and plan". Menurut Notoatmodjo (2007) menyatakan bahwa dukungan merupakan salah satu faktor penentu dari seseorang untuk berperilaku sehat.

Wanita usia subur meskipun tidak mendapatkan dukungan dari keluarga (keluarga istri maupun keluarga suami), tetap memilih menggunakan kontrasepsi MOW karena adanya orang-orang penting selain keluarga yang menjadi referensi. Hal ini berarti perilaku wanita usia subur dalam memilih penggunaan kontrasepsi MOW dipengaruhi oleh kelompok referensi lain, seperti PLKB (petugas lapangan keluarga berencana), kader, maupun petugas kesehatan lainnya (dokter dan bidan). Perilaku orang lain yang dianggap penting bisa menjadi dorongan seseorang untuk merubah perilakunya. Karena mereka lebih mudah mendapatkan pengaruh dari orang 
yang dianggapnya penting (Notoatmodjo, 2003).

\section{Biaya Pelayanan Kontrasepsi}

Biaya pelayanan kontrasepsi tidak berpengaruh signifikan terhadap penggunaan kontrasepsi MOW. Kemungkinan karena adanya Peraturan Menteri Kesehatan Republik Indonesia Nomor 97 Tahun 2014 tentang pelayanan kontrasepsi, pada pasal 18 menyatakan bahwa pelayanan kontrasepsi dilakukan dengan cara yang dapat dipertanggung jawabkan melalui pergerakan pelayanan kontrasepsi, pemberian atau pemasangan kontrasepsi dan penanganan terhadap efek samping, komplikasi dan kegagalan kontrasepsi.

Berdasarkan Peraturan Menteri Kesehatan Republik Indonesia Nomor 97 Tahun 2014 tentang pelayanan kontrasepsi, pemberian atau pemasangan kontrasepsi mendapatkan jaminan dari Pemerintah. Dalam hal ini terutama berlaku bagi pemasangan kontrasepsi jangka panjang (IUD, implan, MOW dan MOP) yang biaya pemasangannya digratiskan oleh pemerintah. Namun dalam beberapa daerah atau wilayah tergantung pada peraturan daerah dan APBD masing-masing wilayah.

Belum terpenuhinya kebutuhan fasilitas kesehatan $\mathrm{KB}$, seperti penyediaan alat transportasi bagi calon akseptor kontrasepsi MOW, menyebabkan calon akseptor harus iuran biaya transportasi dalam upaya untuk menjangkau tempat pelayanan yang berada di wilayah kota. Selama ini calon akseptor secara mandiri membayar iuran sebagai uang ganti rugi transportasi, uang perban pasca operasi.

Akseptor kontrasepsi MOW dalam penelitian cenderung memiliki biaya pelayanan dikarenakan akseptor mendapatkan pelayanan kontrasepsi MOW sesaat pasca persalinan, sehingga mereka termasuk mendapatkan pelayanan $\mathrm{KB}$ swasta bukan pelayanan KB dari Pemerintah. Biaya pelayanan yang harus ditanggung oleh akseptor rata-rata diatas $\mathrm{Rp}$ 1.000.000,00. Akseptor yang mendapatkan pelayanan kontrasepsi dari pemerintah hanya mengeluarkan biaya sebesar $\mathrm{Rp}$ $150.000,00$ sebagai uang ganti transportasi.
Hal ini sejalan dengan penelitian SDKI (2007) yang menyatakan bahwa biaya pelayanan $\mathrm{KB}$ di sektor pelayanan pemerintah lebih rendah dari sektor swasta.

\section{SIMPULAN DAN SARAN}

Responden pengguna kontrasepsi MOW sebagian besar mendapatkan dukungan suami, namun tidak mendapatkan dukungan keluarga. Sebagian besar wanita usia subur pengguna kontrasepsi MOW tidak memiliki beban psikologis. Sebagian besar wanita usia subur yang menggunakan kontrasepsi MOW memiliki biaya pelayanan kontrasepsi. Banyak wanita usia subur yang menggunakan kontrasepsi MOW memiliki motivasi pengaturan kelahiran tergolong rendah.

Berdasarkan hasil analisis, faktor yang bepengaruh dengan penggunaan kontrasepsi MOW adalah dukungan suami $(p=0,027 ; O R=4,143)$ dan biaya psikologis $(p=0,039 ; \quad O R=2,968)$. Responden yang mendapatkan dukungan suami berpeluang 4,143 untuk menggunakan kontrasepsi MOW dan responden yang tidak memiliki beban psikologis berpeluang 2,698 menggunakan kontrasepsi MOW.

\section{SARAN}

Berdasarkan hasil analisis yang telah dilakukan, terdapat beberapa saran bagi pemerintah khususnya BKKBN dan BPPKB Kabupaten Bojonegoro. Pertama, perlu meningkatkan sasaran penyampaian informasi mengenai kontrasepsi MOW, tidak hanya untuk wanita usia subur melainkan juga kepada suami dan keluarga ibu. Kedua, perlu adanya pendampingan oleh petugas kesehatan maupun kader terhadap ibu hamil yang mengandung anak kedua, utamanya pada ibu dengan usia $\geq 35$ tahun untuk memilih kontrasepsi MOW.

Bagi peneliti lain sebaiknya mengembangkan lebih mendalam dengan penelitian kualitatif mengenai faktor dukungan suami dan biaya psikologis terhadap penggunaan kontrasepsi MOW.

\section{DAFTAR PUSTAKA}

Amaral, E., Potter, Joseph., 2015. Determinants of Female Sterilization 
in Brazil 2001-2007. Austin: The University of Texas. Tersedia di: http://www.rand.org/content/dam/ran d/pubs/working papers/WR1000/W R1093/RAND_WR1093.pdf [diakses tanggal 12 Februari 2016]

Andrews, G., 2009. Buku Ajar Kesehatan Reproduksi Wanita Edisi 2. Jakarta: Penerbit Buku Kedokteran EGC

Ajzen, I. 2005. Attitudes, Personality, and Behavior. UK: Open University Press

Bapemas dan KB Jatim, 2014. Laporan Kinerja Tahun 2014. Surabaya: Badan Pemberdayaan Masyarakat dan Keluarga Berencana Provinsi Jawa Timur

Beresford, B., Sloper, T., 2008. Understanding the Dinamics of Decision Making And Choice: A Scoping of Key Psychological Theories to Inform The Design and Analysis of The Panel Study. The University of York: British Library. Tersedia di: http://www.york.ac.uk/inst/spru/pubs /pdf/decisionmaking.pdf [diakses 15 Juni 2016]

BKKBN, 2012. Angka Pemakaian Kontrasepsi Nasional. Tersedia di: http://bkkbn.go.id/kependudukan/sur vey [diakses 10 Januari 2016]

BKKBN, 2013. Survei Demografi dan Kesehatan Indonesia. Jakarta: BKKBN

BKKBN, 2015. Statistik 70 Tahun Indonesia Merdeka. Jakarta: Badan Pusat Statistik

Bulatao, R.A, Lee, R.D., 1983. Determinants of Fertility in Developing Countries Volume 2. New York: Academic Press

Danim, S., 2004. Motivasi Kepemimpinan dan Efektifitas Kelompok. Jakarta: Rineka Cipta

Depkes, 2010. Profil Kesehatan Indonesia. Jakarta: Departemen Kesehatan Republik Indonesia

Dinkes Kabupaten Bojonegoro, 2012. Profil Kesehatan Kabupaten Bojonegoro. Bojonegoro: Dinas Kesehatan Kabupaten Bojonegoro
Dinkes Kabupaten Bojonegoro, 2013. Profil Kesehatan Kabupaten Bojonegoro. Bojonegoro: Dinas Kesehatan Kabupaten Bojonegoro

Dinkes Kabupaten Bojonegoro, 2014. Profil Kesehatan Kabupaten Bojonegoro. Bojonegoro: Dinas Kesehatan Kabupaten Bojonegoro

Dinkes Provinsi Jatim, 2012. Profil Kesehatan Provinsi Jawa Timur. Surabaya: Dinas Kesehatan Provinsi Jawa Timur

Ernest, O., Ebenezeer, O., 2007. The Role of Men in Family Planning Decision Making In Rural and Urban Nigeria. The European Journal of Contraception \& Reproductive Health Care, 12(1): pp: 70. Tersedia http://www.tandfonline.com/doi/abs/ 10.1080/13625180600983108?jornal Cod=iejc20\#.V5DA09Lnako

[Diakses 04 Mei 2016]

Fienalia, R., 2012. Faktor-Faktor yang Berhubungan dengan Penggunaan Metode Kontrasepsi Jangka Panjang (MKJP) di Wilayah Kerja Puskesams Pancoran Mas Kota Depok Tahun 2011. Skripsi. Jakarta: Fakultas Kesehatan Masyarakat Universitas Indonesia

Friedman, M,. Thapa, S,. 1998. Female Sterilization in Nepal: A Comparison of Two Types of Services Delivery. Journal International Family Planning, 24(2): pp.78-83

Hartanto, H., 2003. Keluarga Berencana dan Kontrasepsi. Jakarta: Pustaka Sinar Harapan

Jan, M., Aktar, S., 2008. An Analysis of Decision-Making Power among Married and Unmarried Women. Institute of Home Science, Kashmir: University of Khasmir

Kemenkes RI, 2014. Profil Kesehatan Indonesia. Jakarta: Kementerian Kesehatan Republik Indonesia Lemeshow, S., 1997. Besar Sampel dalam Penelitian Kesehatan. Yogyakarta: Gajah Mada University Press

Manuaba, I.G.B., 1998. Ilmu Kebidanan Penyakit Kandungan dan Keluarga 
Berencana untuk Pendidikan Bidan. Jakarta: EGC

Minhas, S., Sekhon, H., 2013. Psychosocial Determinants of Contraceptive Use Among Women of Reproductive Age in A Rural Area of Maharahtra. International Journal of Medical Research \& Health Sciences, 3(1): pp.53-58

Mochtar, R., 1998. Sinopsis Obstetri Jilid II Edisi 2. Jakarta: EGC

Mosha, I.H., Ruben, R., 2013. Communication, Knowledge, Social Network and Family Planning Utilization among Couples in Mwanza. Tanzania: African Journal of Reproductive Health, 17(3): pp.5769

Notoatmodjo, S., 2003. Pendidikan dan Perilaku Kesehatan. Jakarta: Rineka Cipta

Notoatmodjo, S., 2005. Promosi Kesehatan, Teori dan Aplikasi. Jakarta: Rineka Cipta

Notoatmodjo, S., 2010. Promosi Kesehatan, Teori dan Aplikasi. Jakarta: Rineka Cipta

Prawirohardjo, S., 2008. Ilmu Kebidanan Edisi Ketiga. Jakarta: Yayasan Bina Pustaka Sarwono Prawirohardjo

Peraturan Menteri Kesehatan Republik Indonesia Nomor 97 Tahun 2014 Tentang Pelayanan Kontrasepsi. Jakarta

Rodgers, A., Cahn, K., 2010. Involving Families in Decision Making in Child Welfare. Center for Improvement of Child and Family-Services School of Social Work: Portland State University

Sahin, H., 2003. Reason for not using Family Planning Methods in Eastern Turkey. European Journal of Contraception and reproductive Health Care. 8(1) pp:11

Siquera, A.D., D'Antona, A. O., D'Antona, M. F \& Moran, E.F., 2007. Embodied Decisions: Reversible and Irreversibel Contraceptive Methods among Rural Women in the Brazilian Amazon. Human organization, 185195
Suratum., 2008. Pelayanan Keluarga Berencana dan Pelayanan Kontrasepsi. Jakarta: Trans Info Media

SDKI, 2007. Survei Demografi Indonesia. Badan Pusat Statistik: Jakarta

SDKI, 2012. Survei Demografi Indonesia. Badan Pusat Statistik: Jakarta

Stephenson, R., 2006. District-Level Religious Composition and Adoption of Sterilization in India. Journal Health Popul Nutr, 24(1): pp.101-103

Undang-Undang Republik Indonesia Nomor 52 Tahun 2009 Tentang Perkembangan Kependudukan dan Keluarga Berencana. Jakarta

Winner, B., Peipert, j., Zhao, Q., Buckel, C., Madden, T \& Allswort, J., 2012. Effectiveness of Long-Acting Reversible Contraception. New England Journal of Medicine, 2(1): pp 1998-2008. Tersedia di: http://www.nejm.org/doi/full/10.105 6/NEJMoa1110855\#t=article [diakses 01 April 2016]

WHO, 2011. Family Planning a Global handbook for Providers (2001 Update). United States Agency for International Development Bureau for Global Health Officer of Population and Reproductive Health 